\title{
RAPAKIVI TEXTURE IN PORPHYRITIC DIKES WITHIN THE KARAVANKE GRANITIC MASSIF (SLOVENIA)
}

\author{
META DOBNIKAR, TADEJ DOLENEC AND GIULIANO BELLIENI
}

DOBNIKAR, META, DOLENEC, TADEJ and BELLIENI, GIULIANO 2002. Rapakivi texture in porphyritic dikes within the Karavanke Granitic Massif (Slovenia). Bulletin of the Geological Society of Finland 74, Parts 1-2, 147-157.

The northern Karavanke Granitic Massif straddles the Slovenian-Austrian border. The investigated area lies in northern Slovenia, and extends from the western Slovenian-Austrian border to the east for about $30 \mathrm{~km}$, with a maximum width of $2 \mathrm{~km}$. The massif exhibits a bimodal magmatic association comprising mainly syenogranite and syenite with contemporaneous gabbroic rocks. Rocks of intermediate composition are less abundant and show field, textural and chemical features suggesting that they have formed as a result of the interaction (mixing and mingling) between felsic and mafic magmas. Plagioclasemantled alkali feldspars occur in dikes of porphyritic syenite, which cut larger bodies of gabbroic rocks.

Field, mineralogical, petrographic and geochemical evidences suggest that the porphyritic syenite is a hybrid rock, formed by the interaction of mafic and felsic magmas. The formation of plagioclase-mantled alkali feldspar can be explained by the introduction of alkali feldspar from felsic, syenogranitic magma into more mafic magma, causing local undercooling in the portion of mafic magma surrounding the crystals. This resulted in the growth of cellular plagioclase, with quartz infilling, in a thermally and compositionally equilibrating system.

Key words: dikes, syenites, porphyritic texture, phenocrysts, alkali feldspar, plagioclase, geochemistry, Triassic, Karavanke, Slovenia

Meta Dobnikar and Tadej Dolenec: Department of Geology, Faculty of Natural Sciences and Engineering, University of Ljubljana, Askerceva 12, SI-1000 Ljubljana, Slovenia

E-mail: meta.dobnikar@ntfgeo.uni-lj.si

Giuliano Bellieni: Department of Mineralogy and Petrology, University of $\mathrm{Pa}$ dova, c.so Garibaldi, 37- I- 35122 Padova, Italy 


\section{INTRODUCTION}

Plagioclase-mantled alkali feldspars occur in dikes of porphyritic syenite in the Triassic (Lippolt \& Pidgeon 1974, Scharbert 1975) Karavanke Granitic Massif (KGM) in northern Slovenia. The massif lies along the Periadriatic Line and extends east for about $30 \mathrm{~km}$ from the western Slovenian-Austrian border to the Tertiary sediments of the Pannonic Basin, with the maximum width of about 2 km (Fig. 1; Isailović \& Milićević 1964, Strucl 1970, Exner 1971, 1976, Faninger 1976, Hinterlechner-Ravnik 1978, 1988/89, Mioč \& Žnidarčič 1978, Mioč 1983). It consists predominantly of syenogranite and syenite with contemporaneous gabbroic rocks and intermediate rocks of alkaline character. Large bodies of gabbroic rocks are occasionally cut by dikes of porphyritic syenite that contains plagioclase-rimmed alkali feldspar phenocrysts (rapakivi texture sensu lato; Vorma 1976, Rämö \& Haapala 1995). The rocks of the KGM range in composition from olivine gabbro to syenogranite without any compositional gap (Fig. 2). Field observations as well as petrographic and geochemical features, like occurrence of mafic pillows in the porphyritic syenite, corroded alka- li feldspar megacrysts in the mafic pillows (Fig. 3), rapakivi texture, quartz ocelli with mafic rims around corroded quartz crystals, and dispersion of trace elements indicate bimodal magmatism and interaction of felsic and mafic magmas (mingling and mixing) (Visonà \& Zanferrari 1999, Bole et al. 2001). Rocks of intermediate composition (monzodiorite, monzonite), and porphyritic syenite are hybrids formed by different degrees of interaction between the mafic and felsic magmas.

This paper presents textural, mineralogical and geochemical characteristics of the porphyritic syenite rocks, and their relationship to non-hybrid mafic and felsic rocks, as well as a probable mechanism for the formation of rapakivi texture in the porphyritic syenite dikes.

\section{PETROGRAPHY}

\section{Felsic end member}

Syenogranite constitutes the majority of the massif. It is a fine- to coarse-grained rock and consists of plagioclase $(\mathrm{An}<3 \%)$, alkali feldspar,

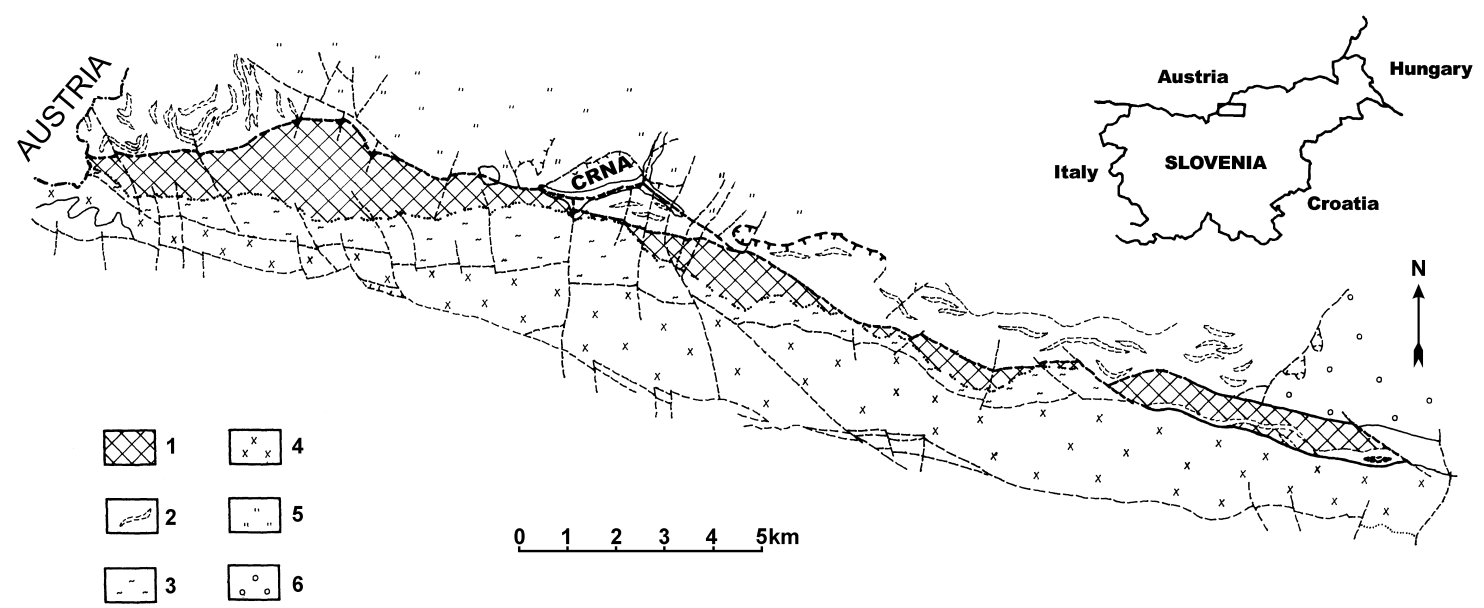

Fig. 1. Geological sketch map of the Karavanke Igneous Zone and investigated area (simplified after Mioč \& Žnidarčič 1978). 1) granitic belt, 2) Paleozoic greenschist with diabase lenses, 3) fine-grained gneiss, 4) tonalite, 5) Triassic dolomite, 6) Miocene conglomerate 


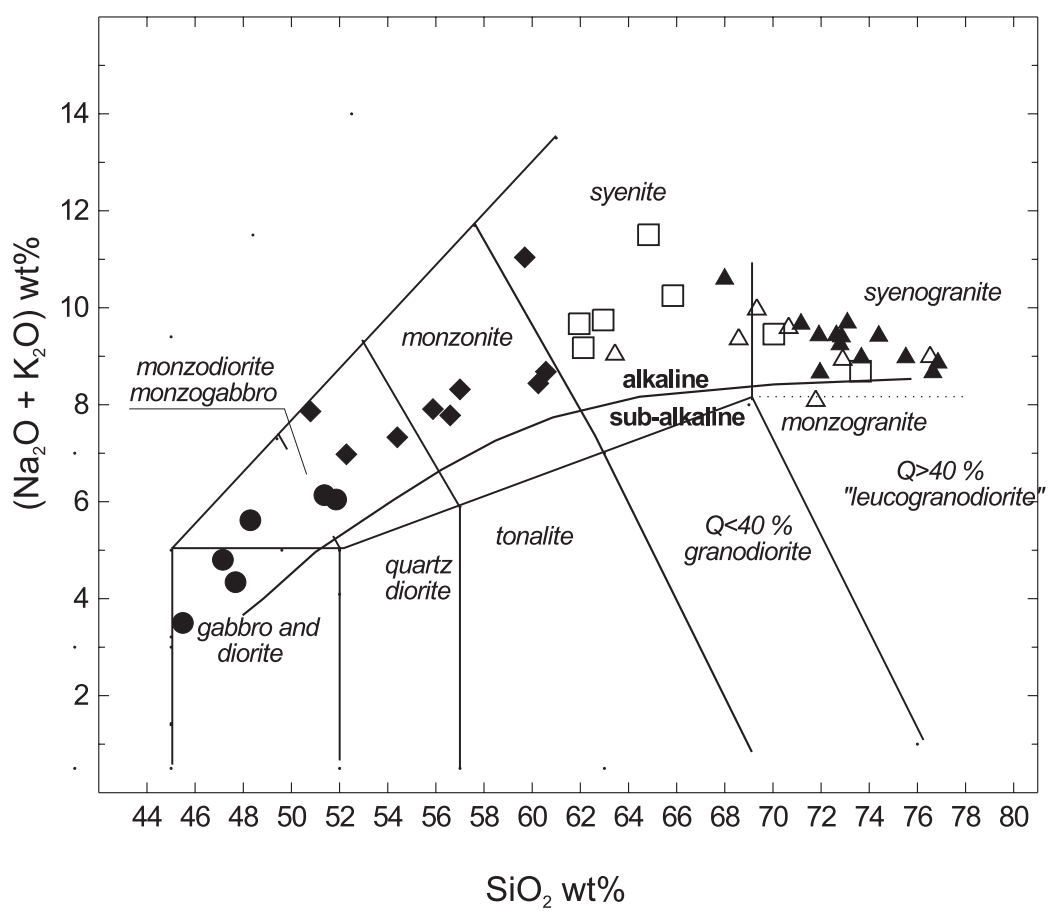

Fig. 2. Classification of Karavanke Granitic Massif rock types after the TAS proposal of Bellieni et al. (1995). Alkaline - subalkaline border from Miyashiro (1978). Values recalculated to Sum ${ }_{O x}=100 \mathrm{wt} \%$. $\bullet$ - mafic rocks, $\checkmark$ - hybrid mafic rocks, $\square$ - porphyritic rocks, $\triangle$ - hybrid felsic rocks, $\boldsymbol{\Delta}$ - felsic rocks.

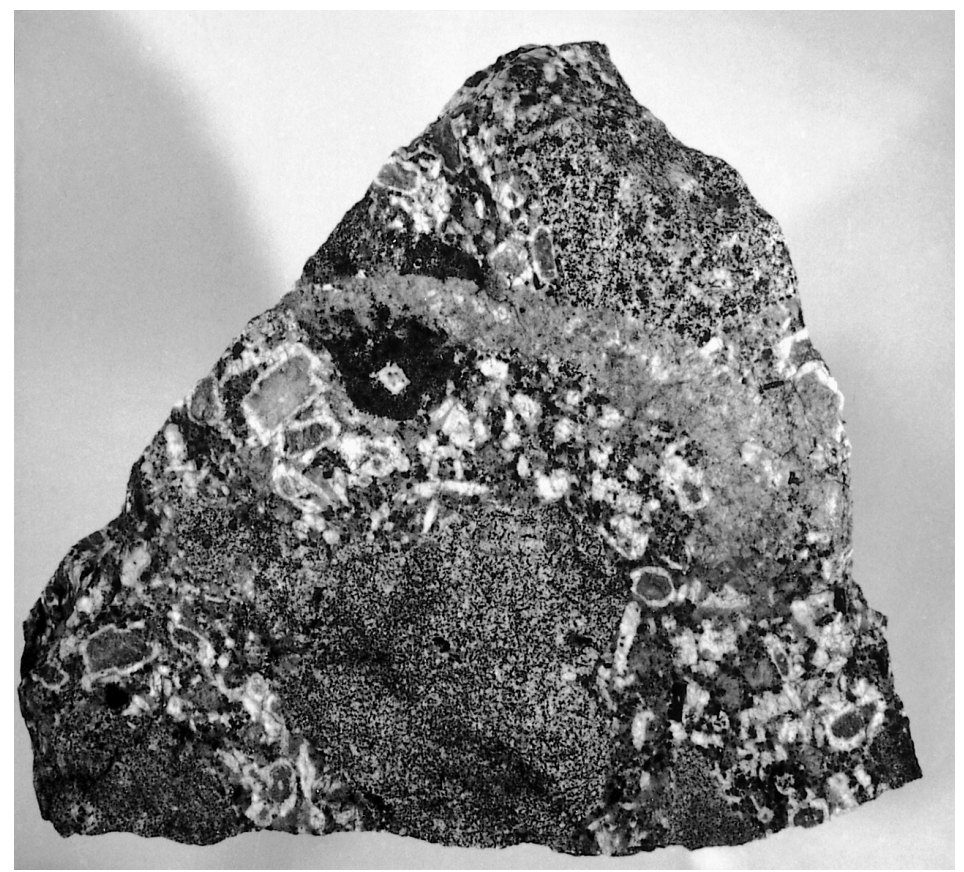

Fig. 3. Intrusive breccia. Width of the bottom of the picture is $40 \mathrm{~cm}$. 
quartz of two generations, as well as rare biotite and hornblende. Plagioclase of the first generation forms euhedral crystals, with concentric inclusions of very small, optically undeterminable minerals, indicating changes in physicochemical conditions during growth of the plagioclase crystals. It also occurs as partly sericitized inclusions within alkali feldspar grains. The second generation of plagioclase is less altered and often overgrows crystals of the first generation with the same optical orientation. The first generation of alkali feldspar is represented by euhedral (up to $30 \mathrm{~mm}$ in coarse-grained syenogranite) crystals of perthite or microcline-perthite containing inclusions of plagioclase, quartz and biotite. The second generation is represented by fine-grained microcline. Myrmekite is observed at the contact between alkali feldspar and plagioclase. Quartz of the first generation forms rounded, sometimes euhedral grains and small inclusions in K-feldspars. The second quartz generation is fine grained and fills intergranular spaces and fissures. Biotite (annite 80-60\%) and hornblende are euhedral. Hornblende crystals are usually corroded by later phases (mostly quartz). In most samples, hornblende is altered to chlorite. In all felsic rocks of the area, accessory minerals are rare $(<0.5 \mathrm{vol} \%)$ and consist of apatite, zircon and allanite. Chlorite and epidote are secondary phases.

\section{Mafic end member}

Decametric bodies of fine to medium-grained $g a b$ bro occur throughout the massif. Their shape and size are difficult to establish due to poor exposure. It contains calcic amphiboles (Mg-hornblende and edenite), plagioclase $\left(\mathrm{An}_{45-70}\right)$, orthopyroxene $\left(\mathrm{Fs}_{22-31}\right)$, and olivine $\left(\mathrm{Fo}_{73-79}\right)$ as the main constituents. Hornblende sometimes replaces pyroxene, or forms worm-like overgrowths with pale green pyroxene. In some samples, there are two generations of hornblende. The first generation is euhedral brown edenite, while the second generation forms fine-grained polycrystalline aggregates of green Mg-hornblende. Plagioclase is a late inter- stitial phase. The accessory minerals are acicular apatite, titanite, zircon, and opaques. Epidote is a secondary phase.

\section{Porphyritic syenite}

The porphyritic syenite occurs only as dikes that cut larger gabbroic bodies of the KGM. It has a fine-grained $(0.1-0.3 \mathrm{~mm})$ matrix that occasionally shows flow texture. The phenocrysts $(2-15$ $\mathrm{mm}$ ) consist predominantly of alkali feldspar with or without plagioclase rim, plagioclase, minor quartz and, in some samples, biotite and amphibole (Fig. 4). The content of phenocrysts varies from around $20 \mathrm{vol} \%$ to $60 \mathrm{vol} \%$ from more mafic to more felsic varieties of the porphyritic syenite.

Except for pyroxene, which is only present in the matrix of the most basic varieties of porphyritic syenite (with $\mathrm{SiO}_{2}$ less than $64 \mathrm{wt} \%$ ), mineral assemblages of matrix and phenocrysts are similar, though amphibole, biotite and plagioclase predominate over alkali feldspar and quartz in the matrix.

Accessory minerals (approx. 3-4 vol\%) consist of apatite, zircon, rutile, and opaque minerals. Secondary minerals are epidote and clinozoisite.

\section{Matrix}

The fine-grained matrix consists predominantly of amphibole and biotite, anhedral plagioclase, and minor amounts of alkali feldspar and quartz. Clinopyroxene is present only in the matrix of the samples with less than $64 \mathrm{wt} \% \mathrm{SiO}_{2}$.

Crystals of amphibole in the matrix are euhedral, devoid of inclusions and are commonly concentrated around quartz phenocrysts. Matrix biotite sometimes surrounds biotite phenocrysts or replaces matrix amphibole. Opaque oxides are commonly surrounded by biotite. Plagioclase is consertally intergrown with anhedral quartz and alkali feldspar in the matrix. It often forms myrmekitic texture with quartz at the margins of the alkali feldspar phenocrysts. 

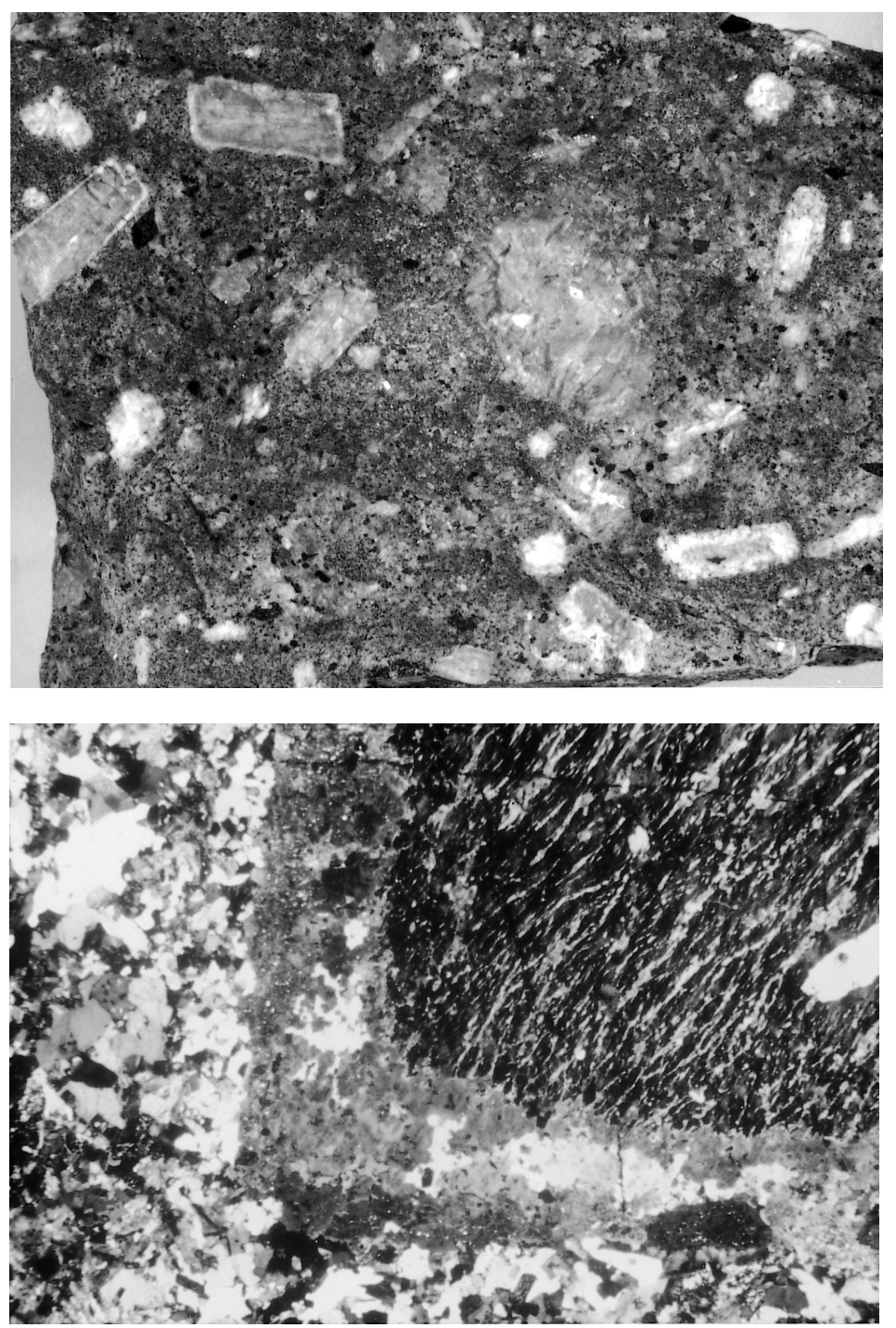

Fig. 4. Porphyritic syenite. Width of the picture is $20 \mathrm{~cm}$.

Fig. 5. Rapakivi texture under sensu lato microscope (crossed nicols). Width of the figure is $1 \mathrm{~cm}$.

\section{Phenocrysts}

Amphibole (ferrohornblende) in most cases constitutes clots and polycrystalline aggregates, often associated with opaque oxides and apatite. In some cases it has a patchy texture, which suggests that it grew after pyroxene. Inclusions of apatite needles and opaque minerals are common and crystal rims are often corroded by quartz and plagioclase. Phenocrysts of amphibole are sometimes replaced by biotite. Biotite (annite 40-50\%) phenocrysts are euhedral, sometimes strongly corroded by quartz or surrounded by matrix amphibole.
Plagioclase $\left(\mathrm{An}_{15-25}\right)$ is euhedral and contains mineral inclusions (e.g. pyroxene, amphibole) indicating that at least some of the phenocrysts crystallized in a mafic magma. Plagioclase crystals are often rimmed by younger plagioclase and occasionally replaced by microcline or perthite, or corroded by quartz. Alkali feldspar is euhedral, pink, perthitic, and contains chadacrysts of plagioclase $\left(\mathrm{An}_{20}\right)$ and quartz. Alkali feldspar phenocrysts are surrounded by $1-5 \mathrm{~mm}$ thick rims of plagioclase $\left(\mathrm{An}_{15-25}\right)$-quartz intergrowth (Fig. 5), forming ra- 

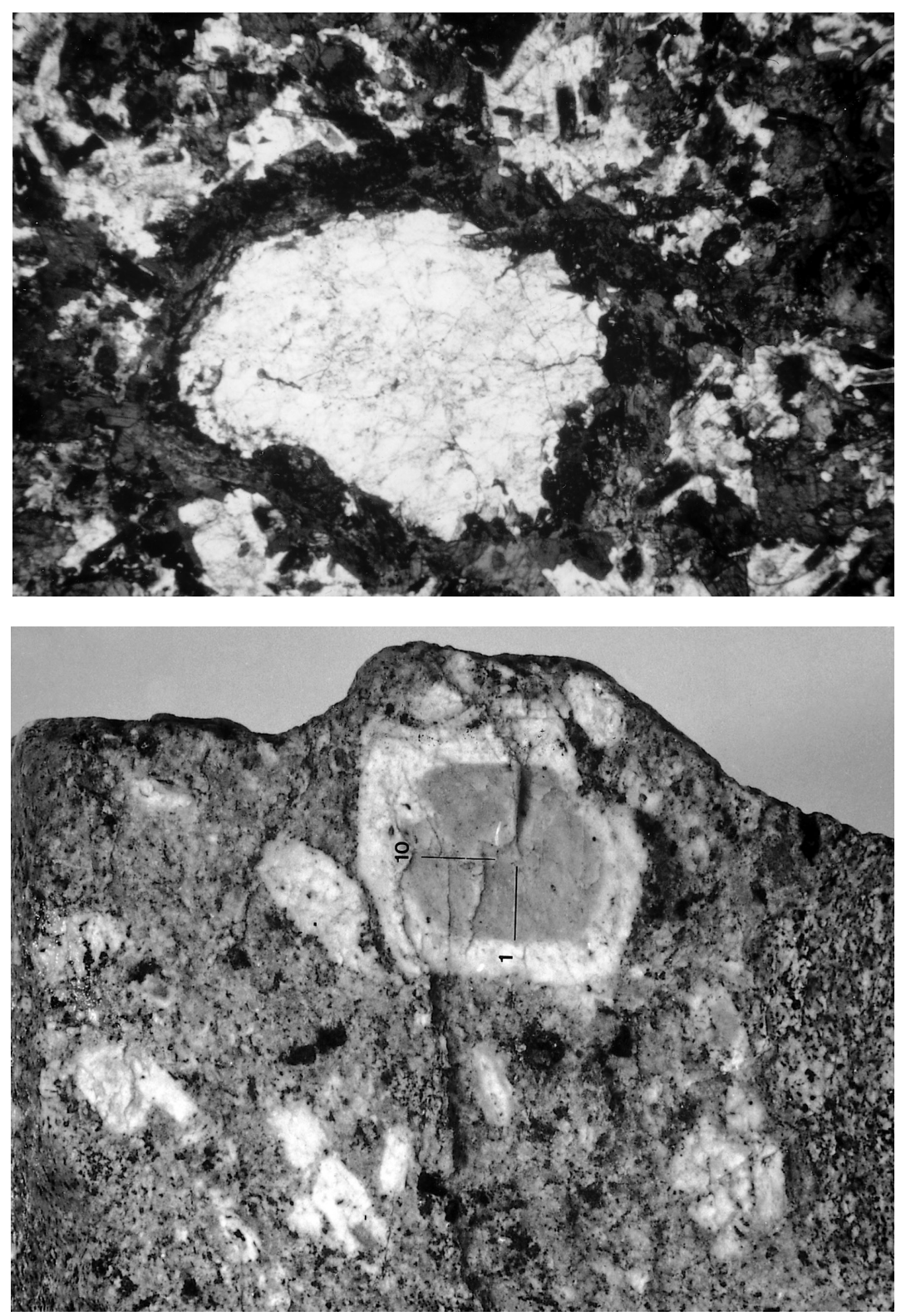

Fig. 6. Ocellar texture under polarised microscope (parallel nicols). Width of the figure is $1 \mathrm{~cm}$.

Fig. 7. Illustration of distribution of measuring points for microprobe analysis on a plagioclase-mantled alkali feldspar.

pakivi texture sensu lato (Vorma 1976, Rämö \& Haapala 1995). The border between the alkali feldspar and its overgrowth is smooth and undulating, and clearly indicates resorbtion before crystallisation of the plagioclase mantle. Quartz grains are rounded and often surrounded by fine-grained pyroxene (when present in the matrix), amphibole, biotite and plagioclase, forming ocellar texture (Blundy \& Sparks 1992) (Fig. 6).
Alkali feldspar megacrysts with plagioclase rims were analysed along profiles by electron microprobe (Fig. 7). The profile analyses are summarised in Table 1. The core is perthitic, consisting of two components - orthoclase $\left(\mathrm{Or}_{98-92}\right)$ and albite $\left(\mathrm{An}_{3}\right)$. Myrmekitic plagioclase around the alkali feldspar phenocrysts is oligoclase in composition $\left(\mathrm{An}_{11}\right.$ to $\mathrm{An}_{24}$ in different samples), with increasing anorthite content towards the matrix. 


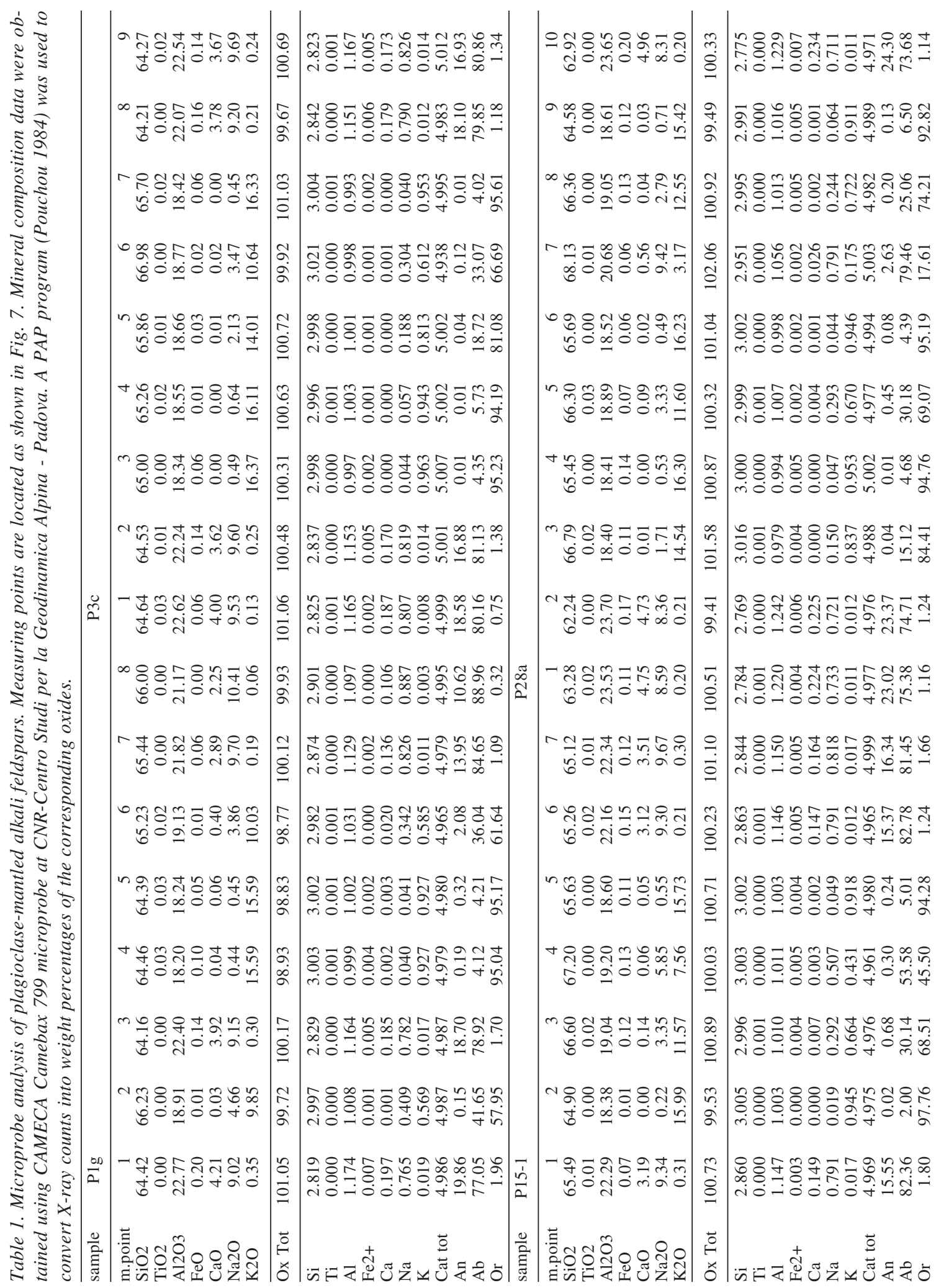




\section{GEOCHEMISTRY}

\section{Felsic end member}

Syenogranite of KGM is meta- to peraluminous (A/CNK=0.85-1.2), transsolvus granite (mesoperthitic alkali feldspar + K-feldspar + albite). Geochemical and mineral chemical data suggest that it was emplaced under an early anorogenic tectonic setting with extensive crustal contamination (Bole et al. 2001). Variation diagrams for major and trace elements (Fig. 8, Fig. 9) for syenogranite show regular trends, that may be interpreted as liquid lines of descent. The REE pattern of syenogranitic rocks (Fig. 10) exhibits strong fractionation for LREE $\left[(\mathrm{La} / \mathrm{Sm})_{\mathrm{N}}=3.7-6.87\right]$, weak frac-

tionation for HREE $\left[(\mathrm{Gd} / \mathrm{Yb})_{\mathrm{N}}=0.69-1.61\right]$, and strong negative Eu anomaly $\left(\mathrm{Eu} / \mathrm{Eu}^{*}=0.28-0.8\right)$.

\section{Mafic end member}

For gabbroic rocks, variation diagrams of major and trace elements vs. $\mathrm{SiO}_{2}$ (Fig. 8, Fig. 9) show trends that might be ascribed to fractional crystallisation. The REE patterns (Fig. 10) are slightly fractionated for LREE $\left[(\mathrm{La} / \mathrm{Sm})_{\mathrm{N}}=2.38-3.16\right]$ and HREE $\left[(\mathrm{Gd} / \mathrm{Yb})_{\mathrm{N}}=1.94-2.42\right]$, with no $\mathrm{Eu}$ anomaly. The relatively flat MORB-normalised
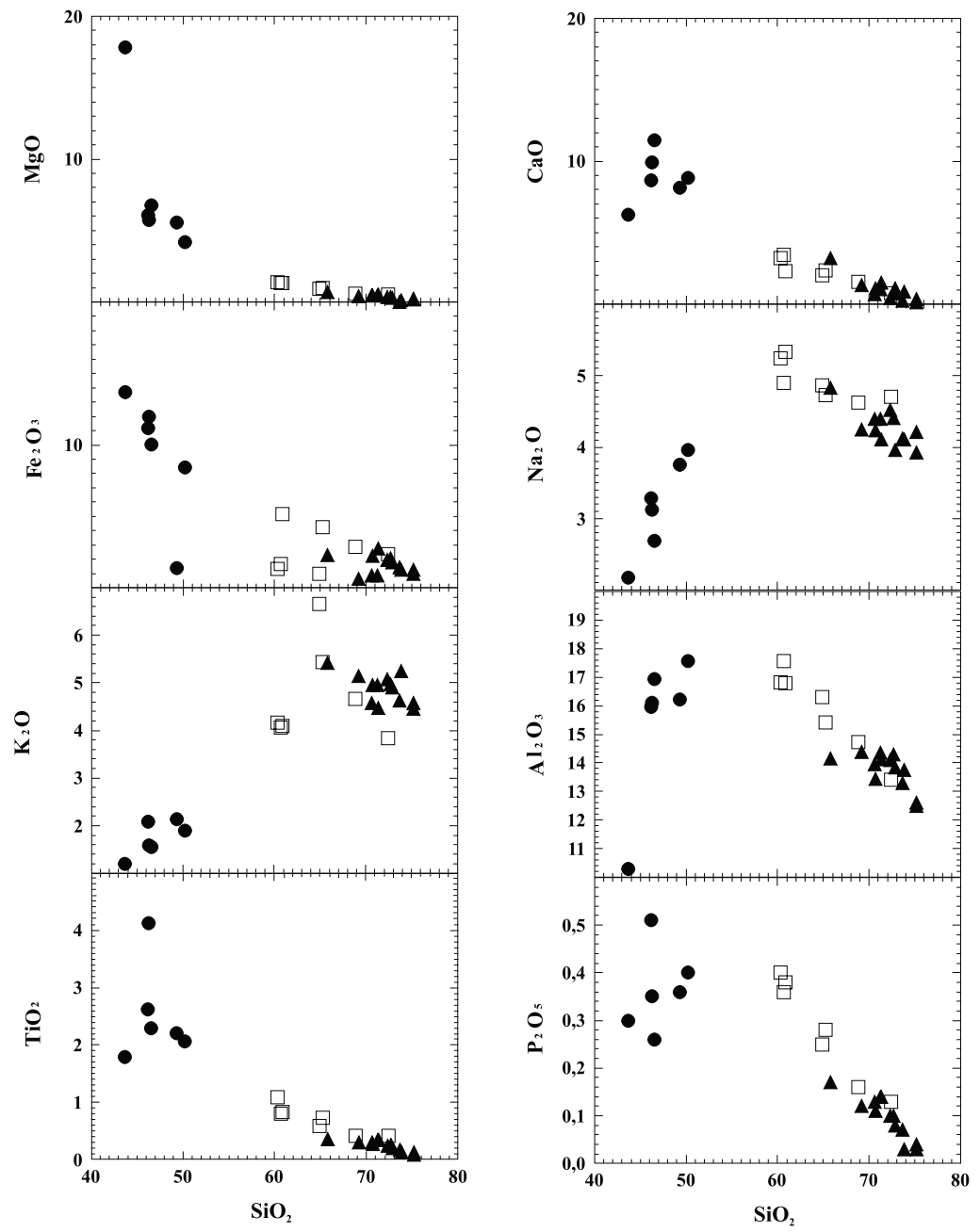

Fig. 8. Major elements (wt\%) vs. $\mathrm{SiO}_{2}$ for porphyritic syenite and nonhybrid mafic and felsic rocks of KGM. Total Fe as $\mathrm{Fe}_{2} \mathrm{O}_{3}$. Symbols as in Fig. 2. 

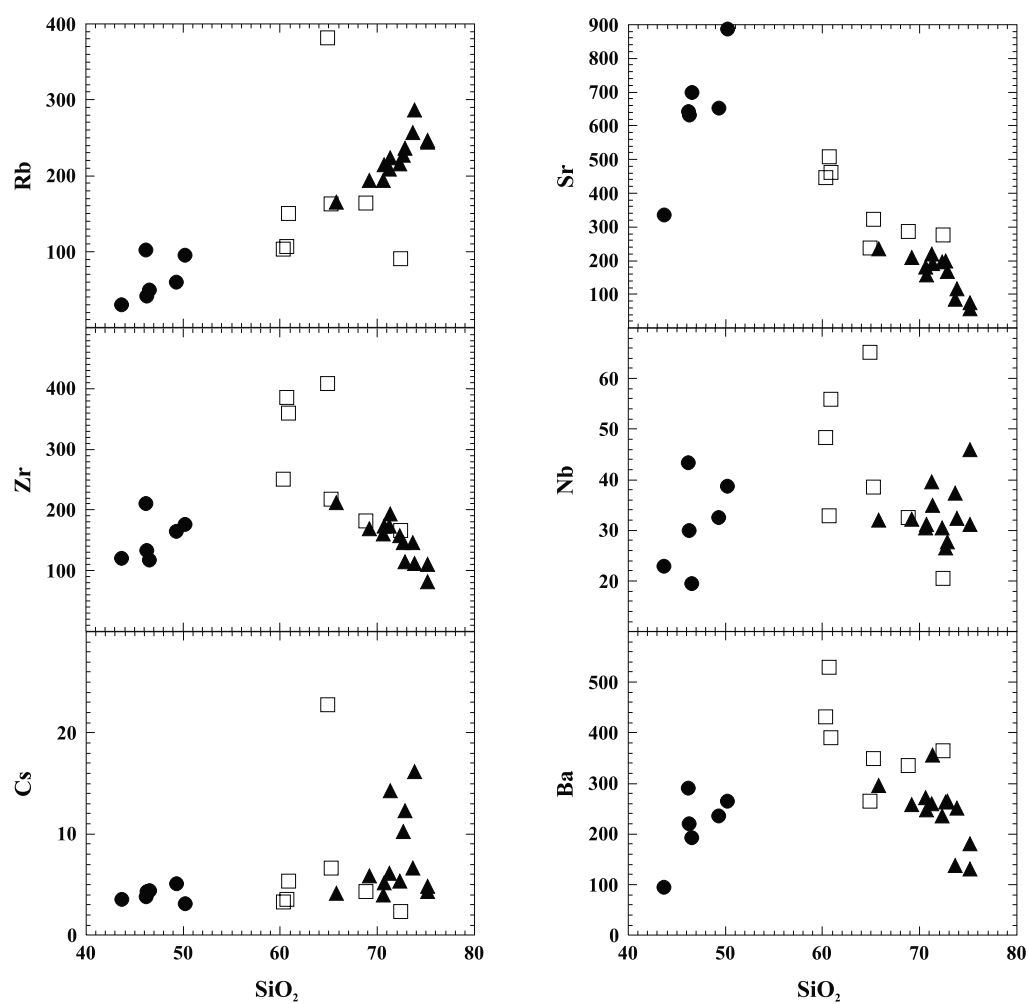

Fig. 9. Trace elements (ppm) vs. $\mathrm{SiO}_{2}$ for porphyritic syenite and nonhybrid mafic and felsic rocks of KGM. Symbols as in Fig. 2.

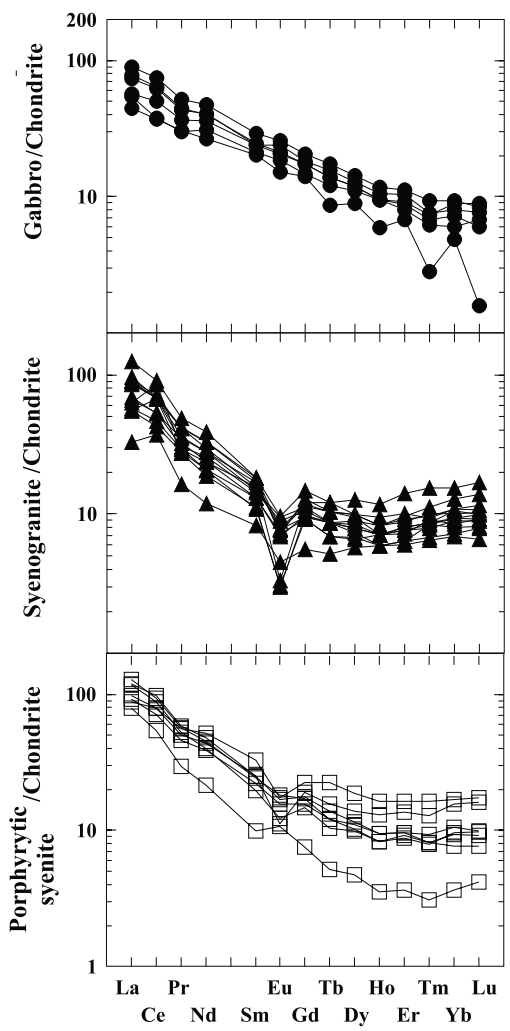

Fig. 10. Chondrite-normalized REE patterns for porphyritic syenite and nonhybrid mafic and felsic rocks of KGM. Chondrite values from Nakamura (1974). Symbols as in Fig. 2. 
REE pattern indicates a common mantle source for the mafic magma (Bole et al. 2001). Enrichment in LIL is also observed, which is a common feature in within-plate basalt provinces according to Bonin (1990, 1997).

\section{Porphyritic syenite}

In the Harker variation diagrams (Fig. 8), the samples of porphyritic syenite plot on the continuation of the felsic-rock liquid lines of descent for $\mathrm{MgO}, \mathrm{TiO}_{2}, \mathrm{CaO}, \mathrm{Na}_{2} \mathrm{O}, \mathrm{Al}_{2} \mathrm{O}_{3}$, and $\mathrm{P}_{2} \mathrm{O}_{5}$. They show $\mathrm{Al}_{2} \mathrm{O}_{3}$ and $\mathrm{P}_{2} \mathrm{O}_{5}$ contents similar to those of mafic rocks and a significant scattering of $\mathrm{K}_{2} \mathrm{O}$ vs. $\mathrm{SiO}_{2}$ values.

In the trace element vs. $\mathrm{SiO}_{2}$ variation diagrams (Fig. 9), most samples of porphyritic syenite plot along the same trends depicted by the felsic rocks, although with a wider scattering. The contents of $\mathrm{Zr}, \mathrm{Nb}$, and $\mathrm{Ba}$ in porphyritic syenite are higher than in both felsic and mafic end members. This appears inconsistent with the hypothesis of a pure mingling/mixing process and suggests participation of different processes.

Porphyritic syenite (Fig. 10) exhibits moderate LREE fractionation $\left[(\mathrm{La} / \mathrm{Sm})_{\mathrm{N}}=2.66-7.96\right]$, and slight HREE fractionation $\left[(\mathrm{Gd} / \mathrm{Yb})_{\mathrm{N}}=1.20-2.29\right]$. Negative Eu anomaly is present in the porphyritic syenite $\left(\mathrm{Eu} / \mathrm{Eu}^{*}=0.5-0.81\right)$, except for one sample which exhibits a positive Eu anomaly $(\mathrm{Eu} /$ $\mathrm{Eu}^{*}=1.22$ ).

\section{DISCUSSION AND CONCLUSIONS}

In the Karavanke Granitic Massif, interaction between mafic and felsic rocks has been invoked by several authors to explain the presence of rocks with intermediate "hybrid" composition (Exner 1971, Visonà \& Zanferrari 2000, Bole et al. 2001). Both mingling and mixing have been regarded as the major processes. Porphyritic syenite, found as dikes within gabbroic bodies, constitutes only a part of the hybrid rocks identified in the KGM (Bole et al. 2001). Field observations, like obvious alkali feldspar xenocrysts in more mafic magmatic enclaves, petrographic and mineral chemi- cal evidences, like the presence of ocellar and rapakivi texture, and matrix being more mafic than megacrysts (Hibbard 1981, Zorpi 1988, Bussy 1990, Castro et al. 1990, Didier \& Barbarin 1991, Salonsaari, \& Haapala 1994, Rämö \& Haapala 1995, Chappel 1996) are consistent with the hypothesis that also these rocks formed mainly by magma mingling and mixing. Scattering of major and trace elements, as observed in the porphyritic syenite, is not unusual in hybrid rocks. However, the high contents of elements like $\mathrm{Na}, \mathrm{Zr}$, $\mathrm{Nb}$, and $\mathrm{Ba}$ in the hybrid rocks compared to the assumed end members cannot be explained by mixing or mingling processes. Other processes must have contributed to the formation of porphyritic syenite, such as (1) local liquid state differentiation realted to the temperature gradient induced by mingling, (2) near solidus metasomatic exchange (Eberz \& Nicholls 1990) or (3) selective partitioning of some elements between two coexisting magmas (Eby 1983).

Within this framework, the rapakivi texture observed in the hybrid porphyritic syenite might be ascribed to the model of Hibbard (1981), in which alkali feldspar from partly crystallised felsic magma is introduced into more mafic magma and local undercooling triggers the growth of cellular oligoclase in a thermally and compositionally equilibrating system. Precipitation of late quartz provides infilling of voids.

ACKNOWLEDGEMENTS. The research was performed with the financial support of the Ministry of Education, Science and Sport, Republic of Slovenia. Thorough revisions and helpful comments of U.B. Andersson and B. Elliott as well as suggestions by A.M. Fioretti are greatly appreciated.

\section{REFERENCES}

Bellieni, G., Visentin, J.E. \& Zanettin, V. 1995. Use of chemical TAS diagram (Total Alkali Silica) for classification of plutonic rocks: Problems and suggestions. Plinius 14, 49-52.

Blundy, J.D. \& Sparks, R.S.J. 1992. Petrogenesis of mafic inclusions in granitoids of the Adamello Massif, Italy. Journal of Petrology 33, 1039-1104. 
Bole, M., Dolenec, T., Zupančič, N. \& Činč Juhant, B. 2001. The Karavanke Granitic Belt (Slovenia) - a bimodal Triassic alkaline plutonic complex. Schweizerische Mineralogische und Petrographische Mitteilungen 81, 23-38.

Bonin, B. 1990. From orogenic to anorogenic settings: evolution of granitoid suites after a major orogenesis. Geological Journal 25, 261-270.

Bonin, B. 1997. Late Variscan magmatic evolution of the Alpine belt: an overview. In: Sinha, A.K., Sassi, F.P. \& Papanikolaou, D. (eds.) Geodynamic Domains in the Alpine-Himalayan Tethys. Oxford and New Delhi: IBH Publishing Pvt. and Rotterdam: A.A. Balkema, 295-314.

Castro, A., Moreno-Ventas, I. \& De la Rosa, J.D. 1990. Microgranular enclaves as indicators of hybridization processes in granitoid rocks, Hercynian Belt, Spain. Geological Journal 25, 391-404.

Chappell, B.W. 1996. Magma mixing and the production of compositional variation within granite suites: Evidence from the granites of Southeastern Australia. Journal of Petrology 37/3, 449-470.

Eberz, W.E., \& Nicholls, I.A. 1990. Chemical modification of enclave magma by post-emplacement crystal fractionation, diffusion and metasomatism. Contributions to Mineralogy and Petrology 104, 47-55.

Eby, N.G. 1983. The identification of silicate-liquid immiscibility process using minor and trace elements distribution. In: Augustithis, S.S., (ed.) The Significance of Trace Elements in Solving Petrogenetic Problems \& Controversies. Athens: Theophrastus Publications S.A., 27-38.

Exner, Ch. 1971. Geologie der Karawankenplutone Östlich Eisenkappel, Kärnten. Mitteilungen der Geologischen Gesellschaft in Wien 64, 1-108.

Exner, Ch. 1976. Die geologische Position der Magmatite des periadriatischen Lineamentes. Verhandlungen der Geologischen Bundesanstalt 2, 3-64.

Faninger, E. 1976. Karavanški tonalit. Geologija 19, 153210.

Hibbard, M.J. 1981. The magma mixing origin of mantled feldspars. Contributions to Mineralogy and Petrology 76, $158-170$.
Hinterlechner-Ravnik, A. 1978. Kontaktnometamorfne kamenine v okolici Črne pri Mežici. Geologija 21, 77-80.

Hinterlechner-Ravnik, A. 1988/89. Ultramafični vključki v granitu Črne na Koroškem v Sloveniji. Geologija 31, 32, 403-414.

Isailović, S. \& Milićević, M. 1964. Geološko kartiranje granita Črne na Koroškem i obodnih tvorevina. Zavod za nuklearne sirovine, Beograd. 53 p.

Lippolt, H.J. \& Pidgeon, R. 1974. Isotopic mineral ages of a diorite from the Eisenkappel Intrusion, Austria. Zeitschrift für Naturforschung 29a, 966-968.

Mioč, P. 1983. Osnovna geološka karta SFRJ 1: 100.000, tolmač za list Ravne na Koroškem (L 33-54). Zvezni geološki zavod, Beograd. 69 p.

Mioč, P. \& Žnidarčič, M. 1978. Osnovna geološka karta SFRJ 1: 100.000, tolmač za list Slovenj Gradec (L 3355). Zvezni geološki zavod, Beograd. 74 p.

Nakamura, N. 1974. Determination of REE, Ba, Fe, Mg, $\mathrm{Na}$ and $\mathrm{K}$ in carbonaceous and ordinary chondrites. Geochimica et Cosmochimica Acta 38, 757-775.

Pouchou, J.L. 1984. A new model for X-ray Microanalysis. La recherche Aerospatiale 3, 167-192.

Rämö, O.T. \& Haapala, I. 1995. One hundred years of rapakivi granite. Mineralogy and Petrology 52, 129-185.

Salonsaari, P.T. \& Haapala, I. 1994. The Jaala-Itti Rapakivi Complex. An example of bimodal magmatism and hybridization in the Wiborg Rapakivi Batholith, Southeastern Finland. Mineralogy and Petrology 50, 21-35.

Scharbert, S. 1975. Radiometrische Altersdaten von Intrusivgesteinen im Raum Eisenkappel (Karawanken, Kärnten). Verhandlungen der Geologischen Bundesanstalt 4, 301-304.

Štrucl, I. 1970. Stratigrafske in tektonske razmere v vzhodnem delu severnih Karavank. Geologija 13, 5-20.

Visonà, D. \& Zanferrari, A. 2000. Some constrains on geochemical features in the Triassic mantle of the easternmost Austroalpine-Southalpine domain: evidence from the Karawanken pluton (Carinthia, Austria). International Journal of Earth Sciences 89, 40-51.

Vorma, A. 1976. On the petrochemistry of rapakivi granites with special reference to the Laitila massif, southwestern Finland. Geological Survey of Finland, Bulletin $285.98 \mathrm{p}$. 